\title{
PENGARUH SUBSTITUSI SERBUK ECENG GONDOK DAN AMPAS TEMPE TERHADAP PRODUKSI JAMUR TIRAM PUTIH (Pleurotus ostreatus)
}

\author{
(The Effect of Water Hyacinth Powder and Tempe Dregs Substitution \\ on The Production of White Oyster Mushroom (Pleurotus ostreatus) \\ Syiwi Ratri Indriyani ${ }^{1}$, Rommy Andhika Laksono ${ }^{2}$, Kasdi Pirngadi ${ }^{2}$ \\ ${ }^{1}$ Mahasiswa Program Studi Agroteknologi, Fakultas Pertanian, Universitas Singaperbangsa Karawang \\ Jl. HS.Ronggo Waluyo, Karawang 41361, Jawa Barat, Indonesia \\ Penulis koresponden: srindriyani10@gmail.com \\ ${ }^{2}$ Program Studi Agroteknologi, Fakultas Pertanian, Universitas Singaperbangsa Karawang \\ Jl. HS.Ronggo Waluyo, Karawang 41361, Jawa Barat, Indonesia \\ Email: rommy.laksono@faperta.unsika.ac.id; bbpadi@litbang.pertanian.go.id
}

Article Submitted: 21-12-2020

Article Accepted: 28-12-2020

\begin{abstract}
In general, the basic material used in the planting media of white oyster mushroom is sawdust. The increasing need for sawdust, without being offset by sufficient availability will make sawdust difficult to obtain. The research aimed to obtain the composition substitution of the hyacinth powder and tempe dregs which provided the highest results for growth and yield of white oyster mushroom (Pleurotus ostreatus). The research was conducted in Gintung Kerta Village, Klari Subdistrict, Karawang District, West Java from July 2020 to October 2020. The method used was an experimental method with used Randomized Block Design (RDB) single factor, consisting of 9 treatments and 3 replications so there were 27 experimental units. The treatments were: A (without the addition of growing media treatment); B (5\% water hyacinth powder); C (10\% water hyacinth powder); D (15\% water hyacinth powder; E (20\% water hyacinth powder); F (Tempe dregs 5\%); G (Tempe dregs 10\%); H (Tempe dregs 15\%); and I (Tempe dregs 20\%). The results showed that there was a significant effect of composition proportion substitution of the hyacinth powder and tempe dregs on the length of mycelium per baglog, maximum fruit hood diameter per baglog, harvest intensity per baglog, fresh weight of mushrooms per baglog, and total yield in a planting period. The treatment of $\mathrm{H}$ (Tempe dregs $15 \%$ ) gave the highest yield to the harvest intensity of 2.44 times, the mushroom fresh weight of $89.42 \mathrm{~g} / \mathrm{baglog}$, and the total yield in a planting period of $408.00 \mathrm{~g}$.
\end{abstract}

Keywords: water hyacinth powder, tempe dregs

\section{PENDAHULUAN}

Jamur merupakan salah satu sumber hayati yang hidup liar di alam, banyak ditemukan di hutan-hutan Indonesia. Beberapa jenis jamur banyak dimanfaatkan sebagai bahan pangan, karena mengandung banyak nutrisi penting yang dibutuhkan oleh tubuh, salah satunya spesies Pleurotus ostreatus atau yang dikenal dengan nama lokal jamur tiram putih. Jamur tiram putih merupakan salah satu jenis jamur yang paling banyak dikenal karena memiliki rasa yang lezat dan bergizi tinggi. Sehingga menjadi salah satu jamur yang telah banyak dibudidayakan dan diperdagangkan di Indonesia (Prassatia, 2020).

Jamur tiram putih dapat tumbuh pada media yang mengandung nutrisi yang 
menunjang pertumbuhannya seperti lignin, karbohidrat (selulosa dan glukosa), protein, nitrogen, serat, dan vitamin. Senyawa ini dapat diperoleh dari serbuk kayu gergaji, bekatul, jerami, sekam, dan tepung beras (Yuniasmara et al., (1999) Dalam Aini dan Kuswytasari (2013)).

Seiring populernya budidaya jamur tiram di kalangan masyarakat, maka kebutuhan serbuk gergaji kayu sebagai bahan pokok media tanam (baglog) akan semakin meningkat. Kebutuhan serbuk gergaji kayu yang meningkat, tanpa diimbangi dengan ketersediaan bahan tersebut akan menyebabkan serbuk gergaji kayu sulit diperoleh (Hidayat et al., 2019). Sehingga perlu adanya alternatif komposisi media tanam lain yang dapat dijadikan sebagai pengganti dari serbuk kayu, apabila serbuk kayu sulit diperoleh di lokasi budidaya jamur tiram.

Eceng gondok (Eichornia crassipes) merupakan gulma air yang memiliki kemampuan tumbuh dan berkembang sangat cepat. Tingkat pertumbuhan eceng gondok dapat mencapai $1,9 \%$ per hari, dimana 10 tanaman eceng gondok dapat berkembang menjadi 600.000 tanaman dalam waktu 8 bulan (Suwarno dan Wijianto, 2019). Hal itu menyebabkan ketersediaan eceng gondok melimpah dan mudah diperoleh sepanjang tahun. Namun, tingkat pemanfaatan eceng gondok belum sebanding dengan tingkat pertumbuhannya.

Kandungan serat dalam eceng gondok dapat dimanfaatkan sebagai media tanam jamur tiram putih, karena terdapat kandungan serat yang hampir sama dengan serbuk kayu. Menurut Bolenz et al., (1990) Dalam Nusantara (2016), eceng gondok (Eichornia crassipes) memiliki kandungan selulosa sebesar 25\%, hemiselulosa $33 \%$ dan lignin sebesar $10 \%$.

Selain itu, limbah dari agroindustri yang berpotensi untuk dijadikan media tanam jamur tiram salah satunya adalah ampas tempe. Indonesia merupakan negara produsen tempe terbesar di dunia dan menjadi pasar kedelai terbesar di Asia. Tempe merupakan salah satu produk olahan dari kacang kedelai yang banyak diminati oleh masyarakat. Sebanyak $50 \%$ dari konsumsi kedelai Indonesia dijadikan untuk memproduksi tempe, $40 \%$ tahu, dan $10 \%$ dalam bentuk produk lain (seperti tauco, kecap, dan lain-lain) (Badan Standardisasi Nasional, 2012).

Tingginya minat masyarakat terhadap konsumsi tempe mengakibatkan tingginya tingkat produksi tempe, sehingga limbah yang dihasilkan akan semakin banyak. Melimpahnya limbah yang berasal dari pertanian maupun industri dapat menyebabkan pencemaran lingkungan, sehingga upaya untuk menguranginya dengan cara memanfaatkannya sebagai media jamur tiram putih. Limbah tempe yang dapat digunakan untuk media jamur tiram yaitu limbah padat yang merupakan kulit ari biji kedelai atau yang dikenal dengan ampas tempe.

Kandungan serat kasar pada ampas tempe sebanyak $37,74 \%$, serat kasar tersebut terdiri dari lignin, selulosa, dan hemiselulosa. Menurut Peruzza (2010) Dalam Zulkifliani et al., (2017) kandungan selulosa dalam kulit ari kedelai cukup tinggi, yaitu mencapai $48 \%$ dari berat kering, sedangkan kandungan ligninnya rendah.

\section{METODOLOGI PENELITIAN}

\section{Tempat dan Waktu}

Penelitian dilaksanakan di kumbung budidaya yang berlokasi di Desa Gintungkerta, Kecamatan Klari, Kabupaten Karawang, Jawa Barat pada bulan Juli 2020 sampai Oktober 2020.

\section{Bahan dan Alat}

Bahan-bahan yang digunakan dalam penelitian ini yaitu serbuk gergaji kayu, bekatul, kapur $\left(\mathrm{CaCO}_{3}\right)$, gula, tepung maizena, TSP, serbuk eceng gondok, ampas tempe, bibit F2 jamur tiram putih var. Florida, air, spirtus, desinfektan, alkohol $70 \%$, dan kayu bakar. Alat yang digunakan 
dalam penelitian ini antara lain cangkul, terpal, drum sterilisasi berukuran 2001 , plastik PP berukuran $17 \times 35 \mathrm{~cm}$, tali rafia, hand sprayer, kertas millimeter, penggaris dan alat-alat lain yang mendukung penelitian ini.

\section{Rancangan Penelitian}

Metode yang digunakan adalah metode eksperimen dengan Rancangan Acak Kelompok (RAK) faktor tunggal, terdiri dari 3 ulangan dan 9 perlakuan: A (tanpa substitusi media tanam); B (serbuk eceng gondok 5\%); C (serbuk eceng gondok 10\%); D (serbuk eceng gondok 15\%); E (serbuk eceng gondok 20\%); F (ampas tempe 5\%); G (ampas tempe 10\%); H (ampas tempe 15\%); dan I (ampas tempe 20\%).

\section{Pelaksanaan Penelitian}

1. Persiapan Media Tanam

Tangkai daun eceng gondok dan ampas tempe yang telah dikumpulkan, dibersihkan dari kotoran yang melekat dengan air bersih. Kemudian tangkai eceng gondok dipotongpotong dengan ukuran 1-2 cm. Lalu tangkai eceng gondok dan ampas tempe dijemur di bawah sinar matahari selama 2-3 hari atau sampai benar-benar kering. Setelah bahan tersebut kering, kemudian digiling menggunakan mesin penggiling.

Media tanam terdiri dari serbuk gergaji kayu (komposisinya sebesar 740 g, 703 g, $666 \mathrm{~g}, 629 \mathrm{~g}$, dan $592 \mathrm{~g}$ ), serbuk eceng gondok atau ampas tempe (komposisinya sebesar $0 \mathrm{~g}, 37 \mathrm{~g}, 74 \mathrm{~g}, 111 \mathrm{~g}$, dan $148 \mathrm{~g}$ ), serta bahan-bahan lain seperti bekatul (150 g), kapur $\left(\mathrm{CaCO}_{3}\right)(50 \mathrm{~g})$, glukosa $(20 \mathrm{~g})$, tepung jagung (20 g), dan TSP (20 g). Semua bahan dicampurkan sesuai dengan masingmasing perlakuan. Setelah campuran merata ditambahkan air bersih hingga mencapai kadar air 60-65\%, yang ditandai dengan jika dikepal kemudian kepalan dilepaskan akan membentuk gumpalan media yang tidak hancur

2. Pengomposan, Pengemasan dan Sterilisasi

Bahan media tanam yang telah tercampur sempurna dan lembab dilakukan pengomposan selama 2 hari. Selanjutnya media dibungkus dalam kantong plastik PP dan dipadatkan sampai bobot media sebesar 1 $\mathrm{kg}$. Kemudian diikat menggunakan tali rafia dan dilakukan sterilisasi dengan cara mengukus baglog di dalam drum berukuran 2001 dengan suhu $90-100^{\circ} \mathrm{C}$ selama 6 jam. Selanjutnya dilakukan pendinginan selama 12 jam di ruangan dengan suhu kamar (22$25^{\circ} \mathrm{C}$ ). Pendinginan dilakukan hingga suhu baglog mencapai $25-30^{\circ} \mathrm{C}$.

3. Inokulasi dan Inkubasi

Inokulasi dilakukan dengan cara menaburkan bibit jamur tiram putih $\mathrm{F} 2$ di atas permukaan media tanam sebanyak $10 \mathrm{~g}$ atau setara dengan 1 sendok makan. Kemudian baglog ditutup menggunakan cincin baglog, koran dan diikat dengan karet. Baglog yang sudah diinokulasi disimpan di kumbung secara vertikal dengan suhu 25$30^{\circ} \mathrm{C}$ dan kelembaban $70-80 \%$.

4. Pemeliharaan

Baglog yang sudah dipenuhi miselium disusun dengan posisi horizontal dan ujung plastik baglog dipotong agar memberikan ruang pertumbuhan yang lebih besar.

Jika suhu dan kelembaban kumbung kurang dari batas standar, maka dilakukan penyiraman sebanyak 2-3 kali per hari. Penyiraman dilakukan pada media tanam (baglog), dinding serta lantai dalam kumbung.

\section{Pengumpulan Data}

Variabel yang diamati dalam penelitian ini terdiri dari: (1) panjang miselium per baglog, (2) jumlah rumpun buah per baglog. (3) jumlah tudung buah per baglog, (4) diameter tudung maksimal per baglog, (5) panjang batang maksimal per baglog, (6) intensitas panen, (7) bobot segar jamur per baglog, (8) total hasil panen dalam satu periode tanam.

\section{Analisis Data}

Data hasil penelitian dianalisis menggunakan analisis ragam dan apabilla uji $\mathrm{F}$ taraf $5 \%$ menunjukkan hasil yang 
signifikan, maka dilakukkan uji Duncan Multiple Range Test (DMRT) pada taraf 5\%.

\section{HASIL DAN PEMBAHASAN}

\section{Panjang Miselium (cm)}

Berdasarkan hasil analisis ragam menunjukkan terdapat pengaruh nyata akibat substitusi serbuk eceng gondok dan ampas tempe pada media tanam terhadap rerata panjang miselium jamur tiram pada umur 7 , $10,13,16,19,22,25,28$, dan 31 hari setelah inokulasi (hsi). Pengaruh substitusi serbuk eceng gondok dan ampas tempe terhadap panjang miselium jamur tiram putih (Pleurotus ostreatus) disajikan pada Tabel 1.

Tabel 1. Pengaruh substitusi serbuk eceng gondok dan ampas tempe terhadap panjang miselium jamur tiram putih (Pleurotus ostreatus).

\begin{tabular}{crrrrrrrrr}
\hline \multirow{2}{*}{ Perlakuan } & \multicolumn{8}{c}{ Panjang Miselium (cm) Pada Berbagai Umur Pengamatan (HSI) } \\
\cline { 2 - 10 } & \multicolumn{1}{c}{10} & \multicolumn{1}{c}{13} & 16 & 19 & 22 & 25 & 28 & 31 \\
\hline $\mathrm{A}$ & $5,30 \mathrm{ab}$ & $7,69 \mathrm{a}$ & $10,07 \mathrm{a}$ & $12,46 \mathrm{ab}$ & $14,71 \mathrm{ab}$ & $16,76 \mathrm{a}$ & $18,40 \mathrm{a}$ & $19,92 \mathrm{ab}$ & $20,93 \mathrm{a}$ \\
$\mathrm{B}$ & $5,21 \mathrm{ab}$ & $7,48 \mathrm{a}$ & $10,04 \mathrm{a}$ & $12,44 \mathrm{ab}$ & $14,67 \mathrm{ab}$ & $16,40 \mathrm{a}$ & $18,39 \mathrm{a}$ & $19,83 \mathrm{~b}$ & $20,71 \mathrm{a}$ \\
$\mathrm{C}$ & $3,63 \mathrm{~cd}$ & $5,96 \mathrm{~b}$ & $8,04 \mathrm{bc}$ & $10,21 \mathrm{c}$ & $11,88 \mathrm{c}$ & $14,00 \mathrm{~b}$ & $15,81 \mathrm{~b}$ & $17,48 \mathrm{~d}$ & $19,01 \mathrm{c}$ \\
$\mathrm{D}$ & $4,65 \mathrm{~b}$ & $6,21 \mathrm{~b}$ & $7,88 \mathrm{c}$ & $9,39 \mathrm{c}$ & $10,77 \mathrm{c}$ & $11,97 \mathrm{c}$ & $13,31 \mathrm{c}$ & $14,77 \mathrm{e}$ & $16,53 \mathrm{~d}$ \\
$\mathrm{E}$ & $4,41 \mathrm{bc}$ & $6,36 \mathrm{~b}$ & $7,93 \mathrm{c}$ & $9,44 \mathrm{c}$ & $10,74 \mathrm{c}$ & $11,97 \mathrm{c}$ & $13,36 \mathrm{c}$ & $14,64 \mathrm{e}$ & $16,13 \mathrm{~d}$ \\
$\mathrm{~F}$ & $5,65 \mathrm{a}$ & $7,72 \mathrm{a}$ & $10,39 \mathrm{a}$ & $12,78 \mathrm{a}$ & $15,09 \mathrm{a}$ & $17,03 \mathrm{a}$ & $18,84 \mathrm{a}$ & $20,07 \mathrm{a}$ & $20,94 \mathrm{a}$ \\
$\mathrm{G}$ & $5,70 \mathrm{a}$ & $7,98 \mathrm{a}$ & $10,53 \mathrm{a}$ & $13,17 \mathrm{a}$ & $15,23 \mathrm{a}$ & $17,39 \mathrm{a}$ & $19,57 \mathrm{a}$ & $20,56 \mathrm{a}$ & $20,96 \mathrm{a}$ \\
$\mathrm{H}$ & $2,74 \mathrm{~d}$ & $4,63 \mathrm{c}$ & $7,30 \mathrm{c}$ & $9,71 \mathrm{c}$ & $11,87 \mathrm{c}$ & $14,50 \mathrm{~b}$ & $16,70 \mathrm{~b}$ & $18,87 \mathrm{bc}$ & $20,30 \mathrm{ab}$ \\
$\mathrm{I}$ & $3,18 \mathrm{~d}$ & $5,96 \mathrm{~b}$ & $8,95 \mathrm{~b}$ & $11,57 \mathrm{~b}$ & $13,52 \mathrm{~b}$ & $14,63 \mathrm{~b}$ & $16,58 \mathrm{~b}$ & $18,15 \mathrm{~cd}$ & $19,51 \mathrm{bc}$ \\
\hline
\end{tabular}

Keterangan : Nilai rerata yang diikuti huruf yang sama pada setiap kolom yang sama menunjukkan tidak berbeda nyata pada DMRT $5 \%$.

Tabel 1 menunjukkan bahwa perlakuan $\mathrm{G}$ memberikan hasil tertinggi terhadap panjang miselium jamur tiram putih pada umur $7,10,13,16,19,22,25,28$, dan 31 hsi. Hal ini diduga karena ampas tempe memiliki tekstur yang lebih remah dibandingkan dengan serbuk eceng gondok sehingga dapat terdekomposisi relatif lebih cepat. Proses dekomposisi yang lebih cepat mengakibatkan unsur hara yang dibutuhkan dalam pertumbuhan miselium akan terpenuhi. Hal ini sejalan dengan pendapat Suharnowo et al., (2012), bahwa substrat merupakan sumber nutrisi utama bagi jamur tiram akan tetapi nutrisi-nutrisi tersebut dapat dimanfaatkan apabila senyawa-senyawa kompleks pada substrat sudah terurai menjadi senyawa yang lebih sederhana.

Perlakuan $\mathrm{H}$ dan I menunjukkan hasil yang rendah dibandingkan dengan penggunaan ampas tempe lainnya. Hal ini diduga, banyaknya bibit yang diinokulasi pada media tanam (baglog) memiliki jumlah yang berbeda-beda karena proses inokulasi dikerjakan secara manual oleh tangan manusia yang memiliki kemungkinan adanya ketidakseragaman jumlah bibit yang dimasukkan ke dalam media tanam. Menurut Subaryanto (2011), jumlah bibit yang dimasukkan berpengaruh terhadap pertumbuhan miselium. Semakin banyak bibit yang dimasukkan, maka miselium jamur akan semakin cepat tumbuh pada seluruh media tanam serta dapat menekan pertumbuhan jamur kompetitor.

Perlakuan E memberikan hasil terendah terhadap parameter panjang miselium. Hal ini dapat disebabkan oleh tekstur dari serbuk eceng gondok lebih kasar yang mengakibatkan proses dekomposisi relatif lebih lambat. Selain itu, diduga kandungan silika ( $\mathrm{Si}$ ) dalam eceng gondok 
menjadi salah satu faktor yang mampu menghambat pertumbuhan miselium. Pada perlakuan $\mathrm{B}$ menunjukkan hasil yang tidak berbeda nyata dengan perlakuan $G$ hal ini dapat disebabkan karena konsentrasi eceng gondok pada media B lebih sedikit dibandingkan dengan penggunaan serbuk eceng gondok lainnya. Penambahan konsentrasi serbuk eceng gondok dapat meningkatkan kandungan silika pada media tanam. Hal ini sesuai dengan pendapat Aini dan Kuswytasari (2013), bahwa kandungan silika (Si) yang terlalu tinggi pada media (baglog) dapat mengakibatkan pertumbuhan miselium menjadi lebih lambat, karena unsur silika sulit untuk didegradasi oleh enzim.

\section{Jumlah Rumpun Buah, Jumlah Tudung Buah, Diameter Tudung Maksimal, dan Panjang Batang Maksimal}

Berdasarkan hasil analisis ragam menunjukkan terdapat pengaruh nyata akibat substitusi serbuk eceng gondok dan ampas tempe pada media tanam terhadap parameter diameter tudung buah maksimal per baglog, namun memberikan pengaruh tidak nyata terhadap parameter jumlah rumpun buah per baglog, jumlah tudung buah per baglog, dan panjang batang maksimal per baglog. Pengaruh substitusi serbuk eceng gondok dan ampas tempe terhadap jumlah rumpun buah, jumlah tudung buah, diameter tudung buah maksimal, dan panjang batang maksimal dapat dilihat pada Tabel 2 .

Tabel 2. Pengaruh substitusi serbuk eceng gondok dan ampas tempe terhadap jumlah rumpun buah, jumlah tudung buah, diameter tudung buah maksimal, dan panjang batang maksimal

\begin{tabular}{|c|c|c|c|c|c|}
\hline Kode & Perlakuan & $\begin{array}{c}\text { Jumlah } \\
\text { Rumpun } \\
\text { Buah per } \\
\text { Baglog (buah/ } \\
\text { minggu) }\end{array}$ & $\begin{array}{c}\text { Jumlah } \\
\text { Tudung Buah } \\
\text { per Baglog } \\
\text { (buah/ } \\
\text { minggu) }\end{array}$ & $\begin{array}{c}\text { Diameter } \\
\text { Tudung Buah } \\
\text { Maksimal per } \\
\text { Baglog } \\
\text { (cm/minggu) }\end{array}$ & $\begin{array}{c}\text { Panjang } \\
\text { Batang } \\
\text { Maksimal per } \\
\text { Baglog } \\
\text { (cm/minggu) }\end{array}$ \\
\hline A & $\begin{array}{lll}\text { Tanpa } & \text { Substitusi } & \text { Media } \\
\text { Tanam } & & \end{array}$ & $1,44 \mathrm{a}$ & $16,31 \mathrm{a}$ & $10,53 \mathrm{a}$ & $5,03 \mathrm{a}$ \\
\hline B & Serbuk Eceng Gondok 5\% & $1,25 \mathrm{a}$ & $11,08 \mathrm{a}$ & $9,61 \mathrm{a}$ & $4,19 \mathrm{a}$ \\
\hline $\mathrm{C}$ & Serbuk Eceng Gondok $10 \%$ & $1,43 \mathrm{a}$ & $11,60 \mathrm{a}$ & $10,52 \mathrm{a}$ & $4,93 \mathrm{a}$ \\
\hline $\mathrm{D}$ & Serbuk Eceng Gondok $15 \%$ & $1,11 \mathrm{a}$ & $11,50 \mathrm{a}$ & $8,13 \mathrm{~b}$ & $4,38 \mathrm{a}$ \\
\hline $\mathrm{E}$ & Serbuk Eceng Gondok $20 \%$ & $1,11 \mathrm{a}$ & $13,00 \mathrm{a}$ & $8,06 \mathrm{~b}$ & $4,42 \mathrm{a}$ \\
\hline $\mathrm{F}$ & Ampas Tempe $5 \%$ & $1,39 \mathrm{a}$ & $16,68 \mathrm{a}$ & $10,19 \mathrm{a}$ & 4,95 a \\
\hline G & Ampas Tempe $10 \%$ & $1,46 \mathrm{a}$ & $16,85 \mathrm{a}$ & $10,38 \mathrm{a}$ & 5,46 a \\
\hline $\mathrm{H}$ & Ampas Tempe $15 \%$ & $1,07 \mathrm{a}$ & $16,53 \mathrm{a}$ & $10,29 \mathrm{a}$ & $5,52 \mathrm{a}$ \\
\hline I & Ampas Tempe $20 \%$ & $1,39 \mathrm{a}$ & $13,81 \mathrm{a}$ & $9,78 \mathrm{a}$ & $4,68 \mathrm{a}$ \\
\hline
\end{tabular}

Keterangan : Nilai rerata yang diikuti huruf yang sama pada setiap kolom yang sama menunjukkan tidak berbeda nyata pada DMRT $5 \%$.

Substitusi serbuk eceng gondok dan ampas tempe pada media tanam berpengaruh tidak nyata terhadap rerata jumlah rumpun buah per baglog dan rerata jumlah tudung buah per baglog, diduga kondisi lingkungan kumbung yaitu suhu dan kelembaban kurang sesuai untuk pembentukan pin head. Rerata suhu harian yang diperoleh selama percobaan sebesar $28,05^{\circ} \mathrm{C}$ dengan rerata kelembaban harian selama percobaan sebesar $73,65 \%$. Pada fase pembentukan pin head suhu yang diperlukan relatif rendah berkisar antara 22$28^{\circ} \mathrm{C}$ dengan kelembaban optimal berkisar antara $75-95 \%$. Suhu lingkungan yang cukup tinggi akan memicu keadaan kumbung menjadi kurang lembab.

Dengan kondisi tersebut, ditemukan beberapa pin head yang gagal tumbuh 
menjadi tubuh buah jamur yaitu ditandai dengan pin head yang muncul berwarna kuning dan mengering. Hal ini sesuai dengan pernyataan Hendri et al., (2016), bahwa suhu dan kelembaban yang dibutuhkan selama pembentukan pin head berkisar antara 16$22^{\circ} \mathrm{C}$ dan $75-95 \%$, akan tetapi pada suhu yang lebih tinggi (sampai $28^{\circ} \mathrm{C}$ ) masih mampu merangsang pembentukan pin head.

Tubuh buah jamur tiram berasal dari calon tubuh buah (pin head) yang berkembang dengan baik, sehingga banyaknya tubuh buah yang terbentuk dipengaruhi oleh jumlah pin head yang muncul. Nutrisi yang terdapat pada media tanam (baglog) terdistribusi pada setiap pin head untuk membentuk tubuh buah jamur tiram. Media dengan proporsi yang sesuai mampu menghasilkan tubuh buah yang optimal. Perlakuan $G$ memiliki nilai rerata tertinggi pada parameter jumlah rumpun buah per baglog dan jumlah tudung buah per baglog, masing-masing sebesar 1,46 buah dan 16,85 buah. Diduga, pada ampas tempe terdapat kandungan serat kasar yang menjadi sumber nutrisi yang dibutuhkan oleh jamur untuk pembentukan dinding sel, yaitu selulosa 54\%, hemiselulosa 20,96\%, serta kandungan lignin yang rendah (Zulkifliani, 2017). Hal ini sejalan dengan pendapat Rahmawati (2017), bahwa selulosa dan hemiselulosa yang terkandung dalam media tanam berfungsi untuk pembentukan jaringan sehingga dapat meningkatkan jumlah tubuh buah jamur tiram.

Hasil analisis ragam menunjukkan bahwa substitusi serbuk eceng gondok dan ampas tempe pada media tanam memberikan pengaruh nyata terhadap rerata diameter tudung maksimal per baglog. Hasil uji lanjut DMRT 5\%, menunjukkan bahwa perlakuan A memberikan diameter tudung buah maksimal tertinggi yaitu sebesar $10,53 \mathrm{~cm}$. Hal ini diduga kandungan nutrisi yang terdapat pada media A telah mampu memenuhi kebutuhan nutrisi untuk pembentukan tudung buah sehingga menghasilkan diameter maksimal terbaik.
Jamur tiram merupakan salah satu jenis jamur pelapuk putih (JPP) yang mampu mendegradasi selulosa dan lignin. Secara alami, jamur tiram tumbuh pada kayu-kayu yang sudah lapuk dengan kondisi lingkungan yang optimal. Menurut Hartati et al., (2010), serbuk gergaji kayu mengandung 45,42\% selulosa, $21 \%$ hemiselulosa dan $26,50 \%$ lignin yang dibutuhkan oleh jamur untuk pertumbuhannya. Hal ini sejalan dengan pendapat Chabibah (2020), bahwa serbuk gergaji kayu merupakan media tumbuh jamur tiram pada habitat aslinya.

Hidayah et al., (2017) menyatakan bahwa media tanam jamur tiram harus mengandung unsur-unsur yang dibutuhkan untuk pertumbuhan jamur seperti nitrogen, kalsium, kalium, fosfor, karbon, protein, dan kitin. Nitrogen merupakan komponen penyusun protein berfungsi dalam pembentukan jaringan yang sedang aktif tumbuh sehingga dapat mempengaruhi diameter tudung buah jamur.

Hasil analisis ragam menunjukkan bahwa substitusi serbuk eceng gondok dan ampas tempe pada media tanam memberikan pengaruh tidak nyata terhadap rerata panjang batang maksimal per baglog. Hal ini berarti, jenis media tanam yang digunakan memiliki kandungan nutrisi yang mampu memenuhi kebutuhan untuk pertumbuhan jamur tiram. Sehingga panjang batang yang dihasilkan cukup baik.

Perlakuan $\mathrm{H}$ memberikan panjang batang maksimal tertinggi. Hal ini diduga, media tanam dengan penambahan ampas tempe $15 \%$ terdapat kandungan nutrisi yang lebih banyak dan optimal untuk pertumbuhan jamur tiram putih. Hal ini sesuai dengan pernyataan Direktorat Gizi (1990) Dalam Widodo dan Wahyudi (2013), bahwa pada kulit ari kacang kedelai terdapat kandungan $37,74 \%$ serat kasar, $34,9 \%$ protein, $0,23 \%$ kalsium, $0,58 \%$ fosfor, dan $26,06 \%$ zat-zat lain. Unsur fosfor dalam media tanam dapat membantu proses asimilasi pada pertumbuhan jamur tiram. 
Dalam pertumbuhan jamur tiram putih perlu ditunjang dengan kondisi lingkungan yang optimal yaitu sesuai dengan habitat aslinya, sehingga faktor lingkungan menjadi penentu keberhasilan dalam budidaya jamur tiram. Menurut Suryani dan Carolina (2017), faktor lingkungan yang dapat mempengaruhi pertumbuhan jamur tiram antara lain sumber nutrisi, suhu, kelembaban, sirkulasi udara, cahaya, dan air. Iklim mikro pada kumbung yang kurang sesuai dengan syarat tumbuh jamur tiram diduga menjadi penyebab perlakuan yang diberikan berpengaruh tidak nyata terhadap parameter panjang batang maksimal. Selain itu, jamur tiram membutuhkan sirkulasi udara yang baik (segar), apabila pasokan oksigen tidak terpenuhi dapat menghasilkan tubuh buah yang kerdil.

\section{Intensitas Panen, Bobot Segar Jamur, dan Total Hasil Panen dalam Satu Periode Tanam}

Berdasarkan hasil analisis ragam terdapat pengaruh nyata akibat substitusi serbuk eceng gondok dan ampas tempe pada media tanam terhadap parameter intensitas panen, bobot segar jamur, dan total hasil panen dalam satu periode tanam. dan total hasil panen dalam satu periode tanam dapat dilihat pada Tabel 3 .

Tabel 3. Pengaruh substitusi serbuk eceng gondok dan ampas tempe intensitas panen, bobot segar jamur, dan total hasil panen dalam satu periode tanam.

\begin{tabular}{clccc}
\hline Kode & \multicolumn{1}{c}{ Perlakuan } & $\begin{array}{c}\text { Intensitas Panen } \\
\text { per Baglog (kali) }\end{array}$ & $\begin{array}{c}\text { Bobot Segar } \\
\text { Jamur per Baglog } \\
(\mathrm{g} / \text { minggu })\end{array}$ & $\begin{array}{c}\text { Total Hasil Panen } \\
\text { dalam Satu } \\
\text { Periode Tanam } \\
(\mathrm{g})\end{array}$ \\
\hline A & Tanpa Substitusi Media Tanam & $1,89 \mathrm{~b}$ & $78,69 \mathrm{~b}$ & $316,00 \mathrm{~b}$ \\
B & Serbuk Eceng Gondok 5\% & $1,67 \mathrm{~b}$ & $53,28 \mathrm{~cd}$ & $178,06 \mathrm{~d}$ \\
C & Serbuk Eceng Gondok 10\% & $1,44 \mathrm{~b}$ & $56,76 \mathrm{c}$ & $208,00 \mathrm{~d}$ \\
D & Serbuk Eceng Gondok 15\% & $1,11 \mathrm{c}$ & $37,83 \mathrm{e}$ & $59,67 \mathrm{e}$ \\
E & Serbuk Eceng Gondok 20\% & $1,00 \mathrm{c}$ & $43,22 \mathrm{de}$ & $105,56 \mathrm{e}$ \\
F & Ampas Tempe 5\% & $1,67 \mathrm{~b}$ & $78,26 \mathrm{~b}$ & $235,06 \mathrm{~cd}$ \\
G & Ampas Tempe 10\% & $2,22 \mathrm{a}$ & $82,61 \mathrm{ab}$ & $381,17 \mathrm{a}$ \\
H & Ampas Tempe 15\% & $2,44 \mathrm{a}$ & $89,42 \mathrm{a}$ & $408,00 \mathrm{a}$ \\
I & Ampas Tempe 20\% & $2,33 \mathrm{a}$ & $61,61 \mathrm{c}$ & $285,67 \mathrm{bc}$ \\
\hline
\end{tabular}

Keterangan : Nilai rerata yang diikuti huruf yang sama pada setiap kolom yang sama menunjukkan tidak berbeda nyata pada DMRT $5 \%$.

Hasil analisis ragam menunjukkan bahwa substitusi serbuk eceng gondok dan ampas tempe pada media tanam memberikan pengaruh nyata terhadap rerata intensitas panen per baglog. Berdasarkan hasil uji lanjut DMRT 5\% bahwa perlakuan $\mathrm{H}$ memberikan intensitas panen per baglog tertinggi sebesar 2,44 kali. Intensitas panen merupakan banyaknya panen (kali) pada setiap baglog dalam satu periode tanam ( 8 msa), panen tidak dilakukan setiap minggu. Tinggi rendahnya intensitas panen dalam satu periode tanam dapat dipengaruhi oleh nutrisi pada media tanam, karena jamur tiram merupakan organisme heterotrof yang dimana untuk pertumbuhannya sangat bergantung pada bahan organik yang terdapat pada media tanamnya.

Perlakuan $\mathrm{H}$ memberikan tertinggi terhadap parameter intensitas panen. Namun, tidak berbeda nyata dengan perlakuan $\mathrm{G}$ dan I, diduga media tanam pada perlakuan tersebut sudah terdekomposisi secara merata pada fase pembentukan tubuh buah jamur 
yang mengakibatkan kandungan nutrisi di dalamnya mampu mendukung pertumbuhan jamur tiram putih sehingga menghasilkan intensitas panen yang tinggi. Karena ampas tempe memiliki tekstur yang remah sehingga memudahkan jamur dalam mendegradasi senyawa kompleks menjadi senyawa yang lebih sederhana sehingga suplai nutrisi dapat terpenuhi. Hal ini diperkuat dengan pendapat Ningsih (2008), bahwa tekstur media tanam dapat mempengaruhi pertumbuhan jamur. Tekstur media tanam yang lembek memudahkan mikroba heterotropik seperti jamur dalam memecah senyawa kompleks menjadi berbagai bahan organik seperti karbon $(\mathrm{C})$, nitrogen $(\mathrm{N})$, fosfor $(\mathrm{P})$, dan lainlain yang berguna untuk pertumbuhan dan perkembangan jamur tiram.

Menurut Wahyuningati (2010), ampas tempe mengandung bahan organik yang tinggi seperti karbohidrat, protein, lemak, fosfor, kalsium, zat besi, dan serat. Ia menyebutkan bahwa dalam $100 \mathrm{~g}$ kulit ari kedelai terdapat kandungan karbohidrat sebesar 35\%, diantaranya terdapat karbohidrat tidak mudah larut dalam air dan sulit dicerna yaitu selulosa (4\%) dan hemiselulosa (15\%). Karbohidrat merupakan sumber utama untuk metabolisme karbon pada jamur tiram. Karbon merupakan unsur makronutrien yang berfungsi sebagai penyusun struktural sel dan sumber energi yang diperlukan oleh jamur tiram.

Perlakuan E memberikan hasil terendah terhadap parameter intensitas panen. Hal ini diduga ketersediaan nutrisi dalam media tanam tidak mampu memenuhi kebutuhan untuk pertumbuhan jamur tiram. Tidak tersedianya nutrisi yang mencukupi diakibatkan oleh media tanam yang belum terdekomposisi sempurna sejak awal hingga akhir periode tanam. Tabel 1 menunjukkan bahwa pada 31 hsi, perlakuan E memberikan hasil terendah terhadap pertumbuhan miselium. Hal ini sejalan dengan pernyataan Hariadi et al., (2013), bahwa pertumbuhan miselium berkorelasi terhadap fase pertumbuhan jamur tiram berikutnya.
Semakin cepat miselium memenuhi baglog maka akan semakin cepat pula pembentukan tubuh buah jamur tiram.

Hasil analisis ragam menunjukkan adanya pengaruh nyata akibat substitusi serbuk eceng gondok dan ampas tempe pada media tanam terhadap rerata bobot segar jamur per baglog dan rerata total hasil panen dalam satu periode tanam. Berdasarkan hasil uji lanjut DMRT 5\%, perlakuan $\mathrm{H}$ memberikan bobot segar jamur dan total hasil panen dalam satu periode tanam tertinggi yaitu sebesar 89,42 gram dan 408,00 gram. Hal ini dapat disebabkan karena media tanam telah mengalami proses dekomposisi secara sempurna, sehingga ketersediaan nutrisi optimal untuk menunjang pembentukan tubuh buah jamur tiram. Sesuai dengan Wahidah dan Saputra (2015), bahwa berat basah jamur berhubungan dengan ketersediaan nutrisi pada substrat seperti lignin, selulosa, protein, senyawa pati, karbon, nitrogen, hidrogen, dan oksigen. Menurut Suharnowo (2012), media tanam yang ditambahkan dengan ampas tempe mengandung karbohidrat yang tinggi karena pada ampas tempe terdapat kandungan karbohidrat sebesar $86 \%$ yang digunakan jamur dalam menyusun sel serta sebagai sumber energi untuk metabolismenya.

Akan tetapi, perlakuan I yang memberikan hasil bobot segar yang rendah dibandingkan perlakuan dengan penambahan ampas tempe lainnya tercantum pada Tabel 3. Hal ini diduga karena terdapat kandungan isoflavon pada kulit ari biji kedelai yang dapat mempengaruhi pertumbuhan dan perkembangan jamur tiram, sehingga menghasilkan bobot segar jamur yang relatif rendah. Apabila semakin banyak konsentrasi ampas tempe yang terdapat pada media tanam, maka senyawa isoflavon yang terakumulasi pada media tanam juga akan semakin banyak. Hal ini sejalan dengan Sadad et al., (2014), bahwa pada kedelai mengandung senyawa isoflavon yang dapat menurunkan pertumbuhan jamur tiram. Isoflavon termasuk kedalam golongan 
flavonoid yang merupakan metabolit sekunder yang berfungsi sebagai antimikroba, antifungal, dan antivirus.

Selain itu, umumnya tubuh buah jamur tiram memiliki kadar air yang tinggi. Pada saat percobaan, media tanam diberikan penyiraman rutin dengan cara disemprot dengan air sebanyak 2 kali setiap harinya. Tingginya kadar air pada tubuh jamur tiram, diduga pada saat penyiraman uap air terserap oleh jamur tiram. Apabila kadar air dalam tubuh buah jamur meningkat, maka bobot segar akan meningkat. Hal ini sejalan dengan Cahya et al., (2014), bahwa jamur tiram memiliki kandungan air yang cukup tinggi yaitu berkisar antara 80-95\%. Tingginya kadar air dalam tubuh buah jamur dapat disebabkan oleh uap air yang jatuh kepermukaan jamur sehingga permukaan jamur menjadi lembab dan bobot segar meningkat.

Total hasil panen yang diperoleh dapat dipengaruhi oleh bobot segar yang dihasilkan serta intensitas panen dalam satu periode tanam. Semakin tinggi intensitas panen jamur tiram yang disertai dengan tingginya bobot segar yang dihasilkan, maka total hasil panen yang diperoleh juga semakin tinggi. Perlakuan $\mathrm{H}$ memberikan total hasil panen dalam satu periode tanam tertinggi, diduga karena bobot segar yang dihasilkan pada perlakuan $\mathrm{H}$ memberikan hasil tertinggi, sedangkan pada perlakuan D bobot segar yang dihasilkan rendah.

Rendahnya bobot segar yang dihasilkan pada perlakuan $\mathrm{D}$ diduga dipengaruhi oleh pertumbuhan miselium yang tergolong lambat (Tabel 1), sehingga miselium kesulitan memecah senyawa kompleks pada media tanam dan ketersediaan nutrisi untuk pertumbuhan dan perkembangan tubuh buah jamur tiram menjadi kurang optimal. Hal ini sejalan dengan pendapat Luthfian (2017), bahwa berat segar panenan sangat mempengaruhi berat total dari produksi jamur tiram.

Semakin tinggi berat segar jamur yang dipanen, maka total produksi jamur tiram semakin meningkat. Bobot segar jamur setiap panen diikuti dengan penurunan bobot baglog. Hal ini disebabkan karena miselium telah merombak senyawa kompleks pada media tanam menjadi senyawa yang lebih sederhana, sehingga menghasilkan nutrisi yang dapat diserap untuk menunjang pertumbuhan jamur tiram.

\section{KESIMPULAN}

Substitusi serbuk eceng gondok dan ampas tempe pada media tanam memberikan pengaruh nyata terhadap panjang miselium per baglog, diameter tudung buah maksimal per baglog, intensitas panen per baglog, bobot segar jamur per baglog, dan total hasil panen dalam satu periode tanam di Kabupaten Karawang. Perlakuan H (ampas tempe $15 \%$ ) mampu menghasilkan intensitas panen tertinggi sebesar 2,44 kali dengan bobot segar jamur tertinggi sebesar 89,42 gram/baglog, dan total hasil panen dalam satu periode tanam tertinggi sebesar 408,00 gram.

\section{DAFTAR PUSTAKA}

Aini, FN., dan ND. Kuswytasari. 2013. Pengaruh Penambahan Eceng Gondok (Eichhornia crassipes) terhadap Pertumbuhan Jamur Tiram Putih (Pleurotus ostreatus). Jurnal Sains dan Seni Pomits. 2 (1) : 116-120.

Badan Standardisasi Nasional [BSN]. 2012. Tempe: Persembahan Indonesia Untuk Dunia. PUSIDO BSN. Jakarta.

Cahya, M., R Hartanto., dan DD Novita. 2014. Kajian Penurunan Mutu dan Umur Simpan Jamur Tiram Putih (Pleurotus ostreatus) Segar dalam Kemasan Plastik Polypropylene pada Suhu Ruang dan Suhu Rendah. Jurnal Teknik Pertanian Lampung. 3 (1): 35-48.

Chabibah, S. 2019. Pengaruh Substitusi Eceng Gondok (Eichornia crassipes) 
pada Media Tumbuh terhadap Hasil Jamur Tiram Putih (Pleurotus ostreatus) Skripsi. Fakultas Pertanian UNSIKA. Karawang.

Hariadi, N., L Setyobudi dan E Nihayati. 2013. Studi Pertumbuhan dan Hasil Produksi Jamur Tiram Putih (Pleurotus ostreatus) pada Media Tumbuh Jerami Padi dan Serbuk Gergaji. Jurnal Produksi Tanaman. 1 (1) : 47-53.

Hartati, S., E Sudarmonowati., W Fatriasari., E Hermiati., dan W Dwianto. 2010. Wood Characteristic of Superior Sengon Collection and Prospect of Wood Properties Improvement through Genetic Engineering. Wood Research Journal. 1 (2) : 103-105.

Hendri, Y., Samingan dan Z Thomy. 2016. Pengaruh Variasi Jenis dan Komposisi Substrat terhadap Pertumbuhan Jamur Tiram Putih (Pleurotus ostreatus). Jurnal EduBio Tropika. 4 (1) : 19-23.

Hidayat, W., Umrah., dan M Ananda. 2019. Pengamatan Pertumbuhan Miselium Jamur Tiram Putih (Pleurotus ostreatus (Jacq). P.kummer) pada Media Dasar Serbuk Gergaji dengan Suplementasi Ampas Sagu. Biocelebes. 13 (3) : 218-225.

Hidayah, N., E Tambaru, dan A Abdullah. 2017. Potensi Ampas Tebu Sebagai Media Tanam Jamur Tiram (Pleurotus sp). Bioma. 2 (2) : 28-38.

Luthfian, FN. 2017. Pengaruh Kompos Daun Gamal dan Molase sebagai Nutrisi Tambahan dalam Baglog terhadap produksi jamur tiram (Pleurotus ostreatus). Skripsi. Fakultas Pertanian UMY. Yogyakarta.
Ningsih, L. 2008. Pengaruh Jenis Media Tanam dan Konsentrasi terhadap Pertumbuhan dan Produksi Jamur Tiram Merah (Pleurotus flabellatus). Skripsi. Fakultas Sains dan Teknologi UIN Maulana Malik Ibrahim, Malang.

Nusantara, P. 2016. Pemanfaatan Eceng Gondok (Eichornia crassipes) dan Penambahan Air Kelapa dalam Media Tanam Jamur Tiram Putih (Pleurotus ostreatus). Skripsi. Fakultas Keguruan dan Ilmu Pendidikan Universitas Muhammadiyah. Malang.

Prassatia, YA. 2020. Pengaruh Persentase Ampas Tebu dan Jenis Serbuk Kayu terhadap Produksi Jamur Tiram Putih (Pleurotus ostreatus). Skripsi. Fakultas Pertanian Univeristas Muhammadiyah. Palembang.

Rahmawati, JM. 2017. Pemanfaatan Ampas Tahu dan Daun Kelor sebagai Media Tambahan untuk Pertumbuhan dan Produktivitas Jamur Tiram Putih (Pleurotus ostreatus). Skripsi. Fakultas Keguruan dan Ilmu Pendidikan Universitas Muhammadiyah. Surakarta.

Sadad, A., MT Asri., dan E Ratnasari. 2014. Pemanfaatan Bekatul Padi, Bekatul Jagung, dan Kulit Ari Biji Kedelai sebagai Media Pertumbuhan Miselium Cendawan Metarhizium anisopliae. LenteraBio. 3 (2) : 136140.

Subaryanto, DA. 2011. Pengaruh Komposisi Media dan Jumlah Bibit terhadap Pertumbuhan dan Hasil Jamur Merang (Volvariella volvaceae). Skripsi. Fakultas Pertanian UNEJ. Jember. 
Suharnowo, LS Budipramana, dan Isnawati. 2012. Pertumbuhan Miselium dan Produksi Tubuh Buah Jamur Tiram Putih (Pleurotus Ostreatus) dengan Memanfaatkan Kulit Ari Biji Kedelai sebagai Campuran pada Media Tanam. LenteraBio. 1 (3): 125-130

Suryani, T., dan H Carolina. 2017. Pertumbuhan dan Hasil Jamur Tiram Putih pada Beberapa Bahan Media Pembibitan. Bioeksperimen. 3 (1): 73-86.

Suwarno, E dan Wijianto. 2019. Analisis Komposit dengan Penguat Serat Eceng Gondok 50\% dan Serbuk Kayu Sengon 50\% dengan Perlakuan Alkali pada Fraksi Volume 40\%, 50\%, dan 60\% Bematrik Resin Polyester untuk Panel Akuistik. Skripsi. Fakultas Teknik Universitas Muhammadiyah. Surakarta.

Wahidah, BF., dan FA Saputra. 2015. Perbedaan Pengaruh Media Tanam Serbuk Gergaji dan Jerami Padi terhadap Pertumbuhan Jamur Tiram Putih (Pleurotus ostreatus). Biogenesis. 3 (1) : 11-15.
Wahyuningati, TP. 2017. Pengaruh Perbedaan Komposisi Limbah Ampas Tahu dan Kulit Ari Kacang Kedelai terhadap Kadar Nitrogen Pupuk Organik Cair dengan Penambahan EM-4. Skripsi. Fakultas Keguruan dan Ilmu Pendidikan Universitas Sanata Dharma. Yogyakarta.

Widodo, R., dan H. Wahyudi. 2013. Evaluasi Mutu Fisikokimia Roti Berserat Tinggi Berbahan Baku Kulit Biji Kedelai dan Bekatul. Jurnal Agroknow. 1 (1) : 47-56.

Zulkifliani., S. Handayani., Adisyahputra., dan D. Sakarani. 2017. Seleksi Senyawa Penghidrolisis untuk Menghasilkan Gula Reduksi dari Limbah Kulit Ari Kedelai Sebagai Bahan Fermentasi Bioetanol. Bioma. 13 (1) : 1-8. 